\title{
Application of AFLP for taxonomic and epidemiological studies of Photobacterium damselae subsp. piscicida
}

\author{
A. Thyssen, ${ }^{1}$ S. Van Eygen, ${ }^{2}$ L. Hauben, ${ }^{2}$ J. Goris, ${ }^{2}$ J. Swings ${ }^{2}$ \\ and F. Ollevier ${ }^{1}$
}

Author for correspondence: A. Thyssen. Tel: +32 163239 66. Fax: +32 16324575. e-mail: an.thyssen@student.kuleuven.ac.be

\footnotetext{
1 Laboratory of Aquatic Ecology, K. U. Leuven, Ch. De Bériotstraat 32, B-3000 Leuven, Belgium

2 Laboratory for Microbiology, R. U. Gent, K. L. Ledeganckstraat 35, B-9000 Ghent, Belgium
}

\begin{abstract}
A collection of 106 Photobacterium damselae subsp. piscicida strains and 19 Photobacterium damselae subsp. damselae strains, including reference and type strains, were genetically characterized using AFLP. The total genomic DNA of each bacterial strain was digested using restriction endonucleases HindIII and Taql. Using numerical analysis, six clusters were recognized. The largest cluster $(n=106)$ contained the majority of the strains tested and consisted exclusively of Photobacterium damselae subsp. piscicida. The Photobacterium damselae subsp. damselae strains fell outside this cluster. DNA-DNA hybridization experiments showed $77 \%$ DNA binding between the two subspecies, indicating a close genetic relationship. This clearly demonstrates the applicability of AFLP in studying the taxonomic position of Photobacterium damselae subsp. piscicida. In addition, AFLP proved to be a useful genotypic technique for epidemiological surveys of the pathogen, since it was able to discriminate between Mediterranean and Japanese Photobacterium damselae subsp. piscicida isolates.
\end{abstract}

Keywords: AFLP, taxonomy, epidemiology, Photobacterium damselae subsp. piscicida

\section{INTRODUCTION}

Photobacterium damselae subsp. piscicida (formerly Pasteurella piscicida) is the aetiological agent of fish pasteurellosis. This disease was first observed in the USA in populations of wild striped bass (Morone saxatilis) and white perch (Morone americanus) (Snieszko et al., 1964). In 1969, the pathogen became a serious problem in Japan, causing great economic losses in cultured yellowtail (Kusuda \& Yamaoka, 1972). In 1990, Pasteurella piscicida, for the first time, became a threat to the Southern European fish farm industry. In several countries of the Mediterranean area, including France (Baudin Laurencin et al., 1991), Italy (Ceschia et al., 1991), Spain (Toranzo et al., 1991), Greece (Bakopoulos et al., 1995), Portugal (Baptista et al., 1996), Turkey (Candan et al., 1996), Malta (Bakopoulos et al., 1997), Israel (Bakopoulos et al., 1997b) and Croatia (Oraic et al., 1998), the

Abbreviation: UPGMA, unweighted pair group method with averages. pathogen was responsible for severe outbreaks of pasteurellosis in cultured populations of sea bass (Dicentrarchus labrax) and sea bream (Sparus aurata).

The taxonomic position of the pathogen has been controversial. The organism was first placed in the genus Pasteurella and described as Pasteurella piscicida (Janssen \& Surgalla, 1968), although the bacterium was clearly distinguishable from all other species within this genus by a number of morphological and biochemical properties. In 1995, the pathogen was classified in the genus Photobacterium as a subspecies of Photobacterium damselae on the basis of rRNA sequence and DNA-DNA hybridization data (Gauthier et al., 1995). Recent morphological and biochemical characterization tests however, found no phenotypic evidence to include the pathogen as a subspecies of Photobacterium damselae (Thyssen et al., 1998). Various phenotypic and genotypic methods, including morphological and biochemical identification tests, serotyping, lipopolysaccharide and outer-membrane protein profiling, fatty acid methyl ester analysis, plasmid profiling, RFLP of chromo- 
somal DNA and ribotyping have previously been used to characterize Photobacterium damselae subsp. piscicida (Magariños et al., 1997; Thyssen et al., 1998). Most of these techniques proved to be of limited value in discriminating between Photobacterium damselae subsp. piscicida strains, implying that the species was very homogeneous (Toranzo et al., 1983; Magariños et al., 1992; Romaldo et al., 1995).

Amplified fragment length polymorphism (AFLP) is a new genomic fingerprinting method which has been proven to be very useful in epidemiological and evolutionary studies, since it was able to differentiate between highly related bacterial strains belonging to the same species or biovar (Vos et al., 1995; Janssen et al., 1996). In addition, studies have shown that the AFLP technique is a powerful DNA fingerprinting method for bacterial taxonomy (Huys et al., 1996; Janssen et al., 1996).

The aim of this study was to investigate the applicability of the AFLP technique for epidemiological studies of Photobacterium damselae subsp. piscicida. In addition, we determined whether or not AFLP could be used in showing the taxonomic position of this pathogen.

\section{METHODS}

Strains and culture conditions. One hundred and twenty eight strains were examined, the diagnosis was as received and verified as earlier described by using morphological and biochemical identification tests (Thyssen et al., 1998). A total of 106 Photobacterium damselae subsp. piscicida strains were used in this study. The collection contained isolates from Europe $(n=61)$, Japan $(n=43)$ and the USA $(n=2)$, of which 33 were isolated from sea bass, 21 from sea bream, 33 from yellowtail, 4 from Japanese flounder, 4 from striped bass, 2 from mullet and 1 each from red sea bream, black scraper, striped jack, greater amberjack, red spotted grouper, amberjack and white perch. Information concerning the host species was not available for two isolates. The reference strains ATCC 17911, ATCC 29690, ATCC 29689 and ATCC 29688 and the type strain NCMB $2058^{\mathrm{T}}$ of Photobacterium damselae subsp. piscicida were also included in this study. For taxonomic purposes, the type strains of other Photobacterium species were used: NCIMB $1895^{\mathrm{T}}$ (Photobacterium angustum), LMG 4228 ${ }^{\mathrm{T}}$ (Photobacterium leiognathi) and ATCC $7744^{\mathrm{T}}$ (Photobacterium fischeri). Finally, 19 Photobacterium damselae subsp. damselae strains, including two copies of the type strain ATCC $33539^{\mathrm{T}}$ and NCIMB $2184^{\mathrm{T}}$, were analysed. These strains were isolated from various sources, such as sea water, shrimp, oyster, brown shark, European eel, damsel fish and sea bream.

Bacteria were grown on brain-heart infusion agar (Difco) to which $1 \%(\mathrm{w} / \mathrm{v}) \mathrm{NaCl}$ was added and incubated for $48 \mathrm{~h}$ at $26^{\circ} \mathrm{C}$.

\section{AFLP}

Isolation and purification of DNA. Genomic DNA was prepared according to Huys et al. (1996). The DNA concentrations were measured with a fluorimeter (TK 100, Hoeffer). The integrity of the DNA samples were checked on a $1 \%$ agarose gel containing a final concentration of $0.5 \mu \mathrm{g}$ ethidium bromide $\mathrm{ml}^{-1}$ in TAE buffer $(40 \mathrm{mM}$ Tris-acetate, $1 \mathrm{mM}$ EDTA; pH 8.0). Final DNA preparations were stored at $-20{ }^{\circ} \mathrm{C}$.

Preparation of template DNA. All protocols concerning the preparations of template DNA for PCR were performed essentially as described by Vos et al. (1995) and Huys et al. (1996), with minor modifications. In general, $1 \mu \mathrm{g}$ DNA was digested with $15 \mathrm{U} \mathrm{TaqI}$ and HindIII in a final volume of $30 \mu \mathrm{l}$. After restriction, adapters were added at a concentration of $1 \mu \mathrm{M}$ for the HindIII adapter and $20 \mu \mathrm{M}$ for the TaqI adapter (5'-AGCTGGTACGCAGTC-3' and 5'GACGATGAGTCCTGAC-3', respectively) and ligated to the restriction fragments. The TaqI-HindIII templates were precipitated with $1.25 \mathrm{M}$ ammonium acetate and $50 \%(\mathrm{v} / \mathrm{v})$ 2-propanol. Finally, the DNA pellet was washed once with $70 \%(\mathrm{v} / \mathrm{v})$ ethanol and dissolved in $100 \mu \mathrm{T} \mathrm{T} 0.1 \times \mathrm{E}$ buffer (10 mM Tris, $0 \cdot 1 \mathrm{mM}$ EDTA; $\mathrm{pH} 8 \cdot 0)$. Template DNAs were stored at $-20^{\circ} \mathrm{C}$.

AFLP reactions. The TaqI-HindIII restriction fragments tagged with specific adapters were used as template DNA for selective PCR directed by a tetraprimer (5'-CGATGAGTCCTGACCGAA-3') and a hexaprimer (5'-GACTGCGTACCAGCTTA-3') (selective bases at the $3^{\prime}$ ends of the primers are underlined). The hexaprimer was labelled with ${ }^{32} \mathrm{P}$. Selective amplification was performed according to Janssen et al. (1996).

Electrophoresis, autoradiography and data acquisition. All protocols concerning the electrophoresis were done according to Janssen et al. (1996). After electrophoresis, the gel was vacuum-dried with a gel dryer (model 583; Bio-Rad) for $55 \mathrm{~min}$ at $80^{\circ} \mathrm{C}$ as described by Huys et al. (1996). The AFLP fingerprints were visualized autoradiographically by exposing the dried gels to Hyperfilm-MP (Amersham International) for $48-76 \mathrm{~h}$ depending on the amount of radiation determined with a Geiger-Müller counter. After exposure, the films were developed using a Fuji RG II X-Ray film processor. Resulting autoradiograms were scanned by using a high-resolution densitoscanner (X-Ray Scanner). Images were maintained as TIFF files and were further processed using GelCompar version 4.0 software (Applied Maths). The resulting dimension of each gel was 680 by 2683 data points. The size of the TIFF files were decreased by reducing the track resolution (Yres) in the GelCompar conversion program to 1500 data points.

Numerical analysis of banding patterns. Gels were normalized by the alignment of reference tracks which were included at regular intervals in each gel. Background was subtracted using the rolling-disk method which makes part of the GelCompar software package. Gels were combined by assigning one particular reference track as standard and alignment of all other reference tracks against this standard (Janssen et al., 1996). The analysis window was set at 154-1363, excluding the primer and external front. The level of similarity between AFLP fingerprints was calculated using the Pearson product-moment correlation coefficient, in order to avoid subjective interpretations of band positions due to the high number of bands and unequal intensity of bands within a single pattern. The different patterns were clustered by using the unweighted pair group method with average linkage (UPGMA) (Sneath \& Sokal, 1973; Vauterin \& Vauterin, 1992).

DNA-DNA hybridization and DNA base composition. Genomic DNA was extracted and purified by a scaled-up 
variant of the protocol of Pitcher et al. (1989). For analysis of DNA base composition, the DNA was enzymically degraded into nucleosides according to Mesbah et al. (1989). The nucleoside mixture was separated by HPLC using a Waters SymmetryShield C8 column which was maintained at $37^{\circ} \mathrm{C}$. Ammonium acid phosphate $\left(0.02 \mathrm{M} \mathrm{NH}_{4} \mathrm{H}_{2} \mathrm{PO}_{4}\right.$; $\mathrm{pH} 4.0$ ) to which $1.5 \%$ acetonitrile was added, was used as the solvent. Nonmethylated lambda phage DNA (Sigma) was used as the calibration reference. DNA-DNA hybridizations were carried out with photobiotin-labelled probes in microplate wells as described by Ezaki et al. (1989). A HTS7000 Bio Assay Reader (Perkin Elmer) was used for the fluorescence measurements. The hybridization temperature was $37^{\circ} \mathrm{C}$.

\section{RESULTS}

\section{DNA base composition}

The DNA base composition was determined by testing four Photobacterium damselae subsp. piscicida and five Photobacterium damselae subsp. damselae isolates, including the type strains NCIMB $2058^{\mathrm{T}}$, ATCC $33539^{\mathrm{T}}$ and NCIMB $2184^{\mathrm{T}}$. The $\mathrm{G}+\mathrm{C}$ content of Photobacterium damselae subsp. piscicida was measured to be $41 \cdot 1-41 \cdot 3 \mathrm{~mol} \%$, whereas the $\mathrm{G}+\mathrm{C}$ content of Photobacterium damselae subsp. damselae was $40 \cdot 6-41 \cdot 4 \mathrm{~mol} \%$ (Table 1 ). The $\mathrm{G}+\mathrm{C}$ content of the type strains of Photobacterium leiognathi, Photobacterium angustum and Photobacterium fischeri are also given in Table 1.

\section{AFLP genomic fingerprinting}

Choice of restriction enzymes. Based on the DNA base composition, several restriction enzyme combinations, such as EcoRI/MseI and ApaI/TaqI and HindIII/ TaqI, were tested as suggested by Huys et al. (1996). In our study, only restriction with HindIII/TaqI yielded more than 50 clearly separated bands and proved to be the best combination (results not shown). This combination was therefore chosen for the preparation of the DNA templates for PCR of all bacteria used in this study.

Reproducibility of AFLP. Previous studies have shown that AFLP can be considered a highly reproducible fingerprinting technique (Vos et al., 1995; Janssen et al., 1996). In this study, the level of reproducibility within and between gels was determined by including the AFLP pattern obtained on DNA of the type strain of Photobacterium damselae subsp. damselae (ATCC $33539^{\mathrm{T}}$ ) at regular intervals in each electrophoresis run. Following normalization and background subtraction, the similarity between these reference patterns was measured to be at least $90 \%$ within each gel and at least $87 \%$ between gels, using the Pearson product-moment correlation. The differences in the correlation values between the reference lanes were the result of slight variations in background intensities and duration of electrophoresis.

Cluster analysis of AFLP data. After numerical analysis of

Table 1. DNA base compositions and levels of DNA-DNA relatedness

Presented values are the means of three independent experiments, except where indicated otherwise.

\begin{tabular}{|c|c|c|c|c|c|c|c|c|c|c|c|c|c|c|}
\hline \multirow[t]{2}{*}{ Strain } & \multirow[t]{2}{*}{ Cluster } & \multirow{2}{*}{$\begin{array}{c}G+C \text { content } \\
(\mathbf{m o l} \%)\end{array}$} & \multicolumn{12}{|c|}{ DNA-DNA reassociation with $(\%)$} \\
\hline & & & 1. & 2. & 3. & 4. & 5. & 6. & 7. & 8. & 9. & 10. & 11. & 12. \\
\hline \multicolumn{15}{|c|}{ Photobacterium damselae subsp. piscicida strains } \\
\hline 1. ATCC 17911 & $\mathrm{Ia}$ & $41 \cdot 2$ & 100 & 99 & $88^{*}$ & 87 & 69 & 75 & $74 \dagger$ & $71^{*}$ & 73 & $18 \dagger$ & $20 \dagger$ & $18 \dagger$ \\
\hline 2. $510 / 96$ & Ia & $41 \cdot 3$ & 99 & 100 & $94 *$ & 91 & 78 & 78 & $79 \dagger$ & 71 & 79 & $19 \dagger$ & $19 \dagger$ & $20 \dagger$ \\
\hline 3. LA91-197 & $\mathrm{Ib}$ & $41 \cdot 1$ & $101 *$ & $99 *$ & 100 & 101 & 76 & 82 & $72 \dagger$ & 85 & $75^{*}$ & $20 \dagger$ & $22 \dagger$ & $15 \dagger$ \\
\hline 4. NCIMB $2058^{\mathrm{T}}$ & $\mathrm{Ib}$ & $41 \cdot 1$ & 101 & 101 & 95 & 100 & 80 & 83 & $76 \dagger$ & 76 & 82 & $20 \dagger$ & $22 \dagger$ & $19 \dagger$ \\
\hline \multicolumn{15}{|c|}{ Photobacterium damselae subsp. damselae strains } \\
\hline 5. KUL 22 & II & $41 \cdot 3$ & 81 & 84 & 70 & 69 & 100 & 87 & $79 \dagger$ & 77 & 80 & $20 \dagger$ & $22 \dagger$ & $24 \dagger$ \\
\hline 6. ATCC 35083 & IV & $40 \cdot 6$ & 87 & 85 & 69 & 73 & 85 & 100 & $73 \dagger$ & 78 & 87 & $17 \dagger$ & $20 \dagger$ & $25 \dagger$ \\
\hline 7. NCIMB $2184^{\mathrm{T}}$ & $\mathrm{V}$ & $41 \cdot 4$ & $75 \dagger$ & $84 \dagger$ & $77 \dagger$ & $72 \dagger$ & $80 \dagger$ & $92 \dagger$ & $100 \dagger$ & $79 \dagger$ & $86 \dagger$ & $20 \dagger$ & $20 \dagger$ & $15 \dagger$ \\
\hline 8. ATCC $33539^{\mathrm{T}}$ & $\mathrm{V}$ & $40 \cdot 9$ & $84^{*}$ & 85 & 75 & 68 & 82 & 85 & $97 \dagger$ & 100 & 80 & $18 \dagger$ & $19 \dagger$ & $23 \dagger$ \\
\hline 9. $6-58$ & VI & $41 \cdot 2$ & 82 & 83 & $63^{*}$ & 75 & 80 & 85 & $72 \dagger$ & 74 & 100 & $19 \dagger$ & $19 \dagger$ & $22 \dagger$ \\
\hline \multicolumn{15}{|l|}{ Other Photobacterium species } \\
\hline $\begin{array}{l}\text { 10. Photobacterium angustum } \\
\text { NCIMB } 1895^{\mathrm{T}}\end{array}$ & II & $40 \cdot 6$ & $24 \dagger$ & $25 \dagger$ & $23 \dagger$ & $22 \dagger$ & $25 \dagger$ & $25 \dagger$ & $30 \dagger$ & $19 \dagger$ & $30 \dagger$ & $100 \dagger$ & $43 \dagger$ & $29 \dagger$ \\
\hline $\begin{array}{l}\text { 11. Photobacterium leiognathi } \\
\text { LMG } 4228^{\mathrm{T}}\end{array}$ & - & $41 \cdot 6$ & $24 \dagger$ & $27 \dagger$ & $23 \dagger$ & $24 \dagger$ & $26 \dagger$ & $28 \dagger$ & $27 \dagger$ & $19 \dagger$ & $29 \dagger$ & $44 \dagger$ & $100 \dagger$ & $22 \dagger$ \\
\hline $\begin{array}{l}\text { 12. Photobacterium fischeri } \\
\text { ATCC } 7744^{\mathrm{T}}\end{array}$ & - & $38 \cdot 8$ & $7 \dagger$ & $8 \dagger$ & $8 \dagger$ & $9 \dagger$ & $9 \dagger$ & $10 \dagger$ & $9 \dagger$ & $7 \dagger$ & $9 \dagger$ & $9 \dagger$ & $9 \dagger$ & $100 \dagger$ \\
\hline
\end{tabular}

* Results obtained from two experiments.

$\dagger$ Results ontained from a single experiment. 


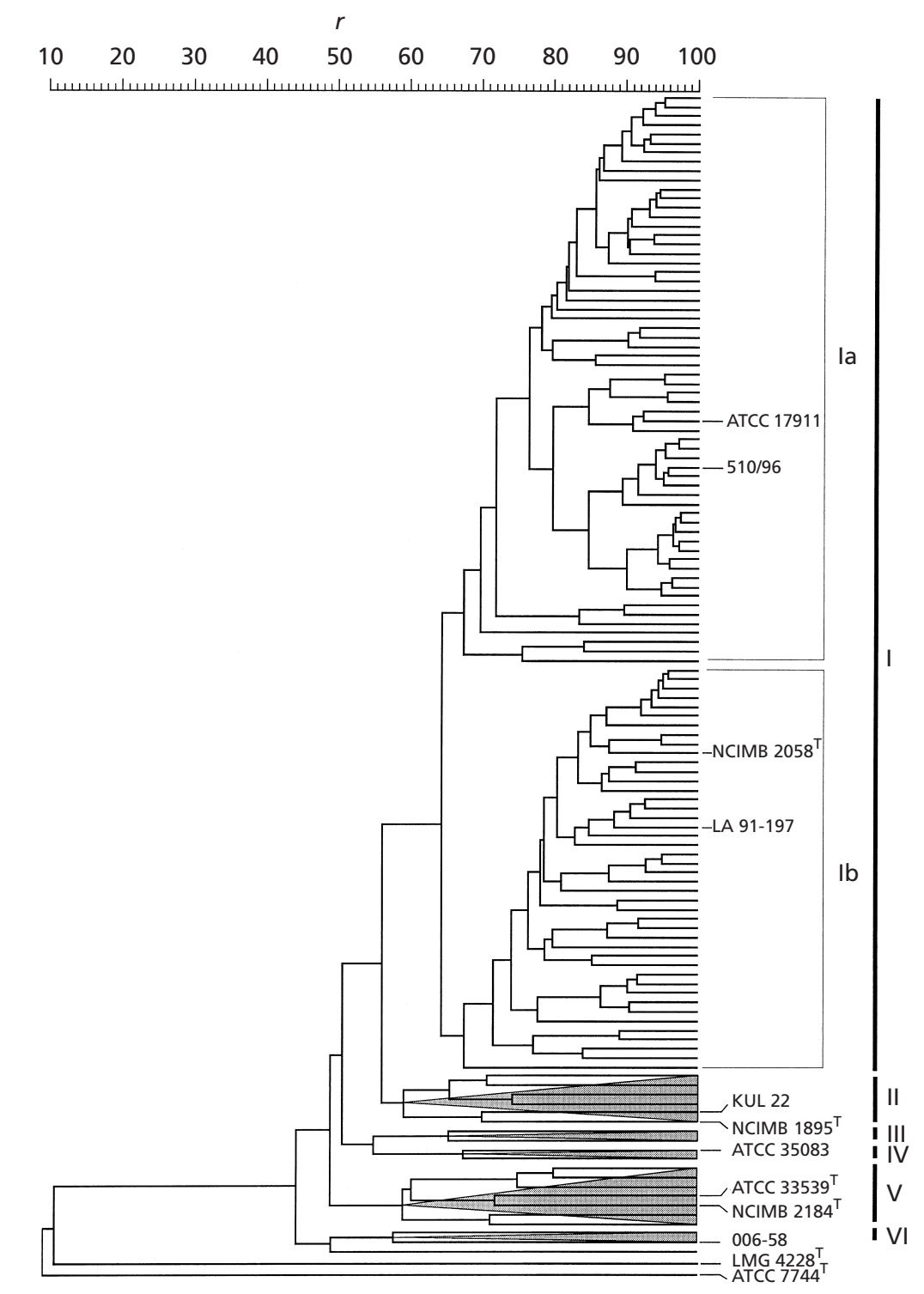

Fig. 1. Dendrogram derived from an UPGMA cluster analysis of the AFLP patterns of all strains used in this study. Levels of linkage are expressed as the Pearson product-moment correlation coefficient $(r)$. The numbers (I-VII) on the right of the dendrogram indicate the cluster to which the strains belong.

the AFLP banding patterns, six clusters could be distinguished at a cut-off value of $57 \%$ similarity (Fig. 1).

Cluster I $(n=106)$ contained the majority of the strains tested and consisted exclusively of Photobacterium damselae subsp. piscicida isolates. The reference strains ATCC 17911, ATCC 29690, ATCC 29689 and ATCC 29688 and the type strain of Photobacterium damselae subsp. piscicida, NCMB $2058^{\mathrm{T}}$, were situated in this cluster. At $66 \%$ similarity, the cluster could be further subdivided into two subclusters, Ia and Ib. Subcluster Ia $(n=62)$ was composed of isolates from the Mediterranean Sea, and also included the American reference strain ATCC 17911, which was isolated from white perch. The strains of subcluster $\mathrm{Ib}(n=44)$ all originated from Japan, with the exception of one that came from the USA (LA91-197) and was isolated from striped bass. Subcluster Ib also included the type strain NCMB
$2058^{\mathrm{T}}$ and the three remaining (Japanese) reference strains.

Cluster II $(n=6)$ contained the type strain of Photobacterium angustum (NCIMB $1895^{\mathrm{T}}$ ) and five strains, including KUL 22 (see Fig. 1), which were received and identified as Photobacterium damselae subsp. damselae based on biochemical characterization tests (Thyssen et al., 1998). These strains originated from sea water, sea bream, European eel and shrimp.

The strains of cluster III $(n=2)$, which formed at $66 \%$ similarity, were isolated from shrimp and identified as Photobacterium damselae subsp. damselae (Thyssen et al., 1998).

Cluster IV $(n=2)$ included the reference strain of Photobacterium damselae subsp. damselae, ATCC 35083, which was isolated from brown shark. Specific information concerning the source of the other isolate 
was not available. Cluster IV joined cluster III at 54\% similarity.

Cluster V $(n=7)$ contained two different cultures (ATCC $33539^{\mathrm{T}}$ and NCIMB $2184^{\mathrm{T}}$ ) of the type strain of Photobacterium damselae subsp. damselae, which clustered together at $71 \%$ similarity. Four strains of cluster $\mathrm{V}$ were from different fish species, whereas the remaining strains originated from environmental sources $(n=1)$ and shrimp $(n=1)$.

The strains of cluster VI $(n=2)$, which formed at $58 \%$ similarity, were isolated from shrimp. At $49 \%$ similarity another strain, isolated from shrimp, joined cluster VI. These strains were identified as Photobacterium damselae subsp. damselae (Thyssen et al., 1998).

The type strains of Photobacterium fischeri (ATCC $7744^{\mathrm{T}}$ ) and Photobacterium leiognathi (LMG $4228^{\mathrm{T}}$ ), joined respectively at a similarity percentage of 12 and 15. The AFLP pattern of these isolates did not only differ from one another, but also displayed a clearly distinct pattern in comparison to all other strains tested.

\section{DNA-DNA hybridization}

DNA-DNA hybridization experiments were carried out by using DNA of four Photobacterium damselae subsp. piscicida isolates and five Photobacterium damselae subsp. damselae isolates, including the type strains NCIMB $2058^{\mathrm{T}}$, ATCC $33539^{\mathrm{T}}$ and NCIMB $2184^{\mathrm{T}}$. Two isolates from cluster Ia and $\mathrm{Ib}$ were chosen to represent Photobacterium damselae subsp. piscicida, whereas representatives of Photobacterium damselae subsp. damselae were located in clusters II, IV, V and VI. DNA-DNA hybridization experiments within the subspecies piscicida showed a mean DNA relatedness of $97 \pm 7 \%(n=32)$, whereas the mean DNA relatedness between the Photobacterium damselae subsp. damselae isolates was $82 \pm 8 \%(n=44)$. Moreover, by DNA-DNA hybridization, the mean DNA binding between Photobacterium damselae subsp. piscicida and Photobacterium damselae subsp. damselae was calculated to be $77 \pm 10 \%(n=100)$ (Table 1). The DNA relatedness between Photobacterium damselae subsp. piscicida and Photobacterium leiognathi, Photobacterium angustum and Photobacterium fischeri on the other hand was much lower, $23 \pm 2 \%(n=8), 21 \pm 2 \%(n=8)$ and $13 \pm 5 \%$ $(n=8)$, respectively.

\section{DISCUSSION}

\section{AFLP}

AFLP is a reproducible technique that has been previously applied in the characterization and identification of bacteria at a subgeneric level (Janssen et al., 1996). In this study, all Photobacterium damselae subsp. piscicida isolates clustered together in one cluster (Fig. 1). Based of this finding, one could say that this subspecies is very homogeneous as previously stated by Magariños et al. (1992), who found that Japanese, European and American strains shared very similar phenotypic, serological and genetic properties. Moreover, fatty acid methyl ester analysis showed a high degree of correlation between the different isolates (Romaldo et al., 1995). In our study however, two distinct groups could be detected within this apparently homogenous subspecies. One subcluster (Ia) contained all European isolates, whereas the other one (Ib) included all Japanese strains. This indicates the existence of two clonal lineages: one Japanese and one European. This finding is in agreement with recent investigations using monoclonal antibodies and ribotyping, which have also shown that strains from the two distinct geographical areas differ from one another and seem to belong to two different clones (Bakopoulos et al., 1997b; Magariños et al., 1997). In contrast to Magariños et al. (1997), no further genetic differentiation between the European strains could be detected, although apparently a subdivision within the European subcluster at $77 \%$ similarity could be seen (subcluster Ia, Fig. 1). This however was neither correlated with geographical origin nor with host-fish species. Kawahara et al. (1998) recently reported serological differences between Japanese strains isolated from yellowtail. In our study, isolates from yellowtail also displayed differences in AFLP banding patterns (results not shown).

In cluster II, the type strain of Photobacterium angustum was found together with five isolates which had been identified biochemically as Photobacterium damselae subsp. damselae. This finding could imply that the five field strains are mis-identified and were in fact Photobacterium angustum. However, according to Thyssen et al. (1998) the five field strains (including KUL 22) were clearly distinguishable from the type strain of Photobacterium angustum (NCIMB $1895^{\mathrm{T}}$ ) by a number of biochemical traits such as motility, $\beta$ haemolysis, growth at 37 and $42{ }^{\circ} \mathrm{C}$, nitrate reduction, growth on MacConkey and thoisulfate/citrate/bile/ sucrose agar, production of lipase, amylase, caseinase, gelatinase and urease, and fermentation from glycerol, saccharose and trehalose. Moreover DNA-DNA hybridization showed a low level of relatedness between KUL 22 and NCIMB $1895^{\mathrm{T}}$ (Table 1). Also the ongoing ribotyping studies using $P v u \mathrm{II}$ as a restriction enzyme, NCIMB $1895^{\mathrm{T}}$ clustered together with the same Photobacterium damselae subsp. damselae strains as in the present study, however, using $M l u \mathrm{I}$, the type strain fell outside the Photobacterium damselae subsp. damselae cluster (A. Thyssen, K. Pedersen, J. L. Larsen \& F. Ollevier, unpublished).

\section{DNA-DNA hybridization}

The results obtained by AFLP were confirmed by results of the DNA-DNA hybridization experiments. In the present study, the DNA-DNA hybridization results showed $97 \%$ DNA binding between the four Photobacterium damselae subsp. piscicida isolates tested. This finding is in accordance with previous 
studies, carried out by Gauthier et al. (1995) who also found a high homogenicity within this subspecies (95\% DNA relatedness). The level of relatedness between the five Photobacterium damselae subsp. damselae on the other hand was calculated to be $82 \%$, indicating that this subspecies is more heterogeneous than Photobacterium damselae subsp. piscicida. This perfectly reflects the AFLP dendrogram (Fig. 1). Moreover, the DNA-DNA hybridization study revealed a high level of relatedness between Photobacterium damselae subsp. piscicida and Photobacterium damselae subsp. damselae, showing $77 \%$ DNA binding. The classification of the two different organisms in a single species (i.e. Photobacterium damselae), is therefore justified. This finding was supported by previous studies performed by Gauthier et al. (1995), who found a DNA binding of $80 \%$ between the two subspecies.

\section{Final remark}

Based on our results, it is concluded that AFLP is able to identify and differentiate strains within Photobacterium damselae subsp. piscicida.

\section{ACKNOWLEDGEMENTS}

This study was supported by a personal IWT grant, a FKFO project G.0063.96 and by the Concerted Research Action of the 'Ministerie van de Vlaamse Gemeenschap, Bestuur Wetenschappelijk onderzoek'. Colleagues are thanked for the gift of strains. The statistical help of Dr Paul Janssen and constructive comments of Professor Dr Paul de Vos are appreciated.

\section{REFERENCES}

Bakopoulos, V., Adams, A. \& Richards, R. H. (1995). Some biochemical properties and antibiotic sensitivities of Pasteurella piscicida isolated in Greece and comparison with strains from Japan, France and Italy. J Fish Dis 18, 1-7.

Bakopoulos, V., Peric, Z., Rodger, H., Adams, A. \& Richards, R. H. (1997a). First report of fish pasteurellosis from Malta. J Aquat Anim Health 9, 26-33.

Bakopoulos, V., Adams, A. \& Richards, R. H. (1997b). Serological relationship of Photobacterium damselae subsp. piscicida isolates (the causative agent of fish pasteurellosis) determined by Western blot analysis using six monoclonal antibodies. Dis Aquat Org 28, 69-72.

Baptista, T., Romalde, J. L. \& Toranzo, A. E. (1996). First occurrence of pasteurellosis in Portugal affecting cultured gilthead sea bream (Sparus aurata). Bull Eur Assoc Fish Pathol 16, 92-95.

Baudin Laurencin, F., Pepin, J. F. \& Raymond, J. C. (1991). First observation of an epizootic of pasteurellosis in farmed and wild fish of the French Mediterranean coasts. In Abstracts of the 5th International Conference of the European Association of Fish Pathology, p. 17. Budapest: European Association of Fish Pathologists.

Candan, A., Kucuker, M. A. \& Karatas, S. (1996). Pasteurellosis in cultured sea bass (Dicentrarchus labrax) in Turkey. Bull Eur Ass Fish Pathol 16, 150-153.
Ceschia, G., Quaglio, F., Giorgetti, G., Bertoja, G. \& Bovo, G. (1991). Serious outbreak of pasteurellosis (Pasteurella piscicida) in euryhaliene species along the Italian coasts. In Abstracts of the 5th International Conference of the European Association of Fish Pathology, p. 26. Budapest: European Association of Fish Pathologists.

Ezaki, T., Hashimoto, Y. \& Yabuuchi, E. (1989). Fluorometric deoxyribonucleic acid-deoxyribonucleic acid hybridization in microdilution wells as an alternative to membrane filter hybridization in which radioisotopes are used to determine genetic relatedness among bacterial strains. Int J Syst Bacteriol 39, 224-229.

Gauthier, G., Lafay, B., Ruimy, R., Breittmayer, V., Nicolas, J. L., Gauthier, M. \& Christen, R. (1995). Small-subunit rRNA sequences and whole DNA relatedness concur for the reassignment of Pasteurella piscicida (Sniezko et al.) Janssen and Surgalla to the genus Photobacterium as Photobacterium damsela subsp. piscicida comb. nov. Int J Syst Bacteriol 45, 139-144.

Huys, G., Coopman, R., Janssen, P. \& Kersters, K. (1996). Highresolution genotypic analysis of the genus Aeromonas by AFLP fingerprinting. Int J Syst Bacteriol 46, 572-580.

Janssen, W. A. \& Surgalla, M. J. (1968). Morphology, physiology, and serology of a Pasteurella species pathogenic for white perch (Roccus americanus). J Bacteriol 96, 1606-1610.

Janssen, P., Coopman, R., Huys, G., Swings, J., Bleeker, M., Vos, P., Zabeau, M. \& Kersters, K. (1996). Evaluation of the DNA fingerprinting method AFLP as a new tool in bacterial taxonomy. Microbiology 142, 1881-1893.

Kawahara, E., Fukuda, Y. \& Kusuda, R. (1998). Serological differences among Photobacterium damselae subsp. piscicida isolates. Fish Pathol 33, 281-285.

Kusuda, R. \& Yamaoka, M. (1972). Etiological studies on bacterial pseudotuberculosis in cultured yellowtail with Pasteurella piscicida as the causative agent. I. On the morphological and biochemical properties. Bull Jpn Soc Sci Fish 38, 1325-1332.

Magariños, B., Romaldo, J., Bandin, I., Fouz, B. \& Tozanzo, A. E. (1992). Phenotypic, antigenic, and molecular characterization of Pasteurella piscicida strains isolated from fish. Appl Environ Microbiol 58, 3316-3322.

Magariños, B., Osorio, C. R., Toranzo, A. E. \& Romaldo, J. (1997). Applicability or ribotyping for intraspecific classification and epidemiological studies of Photobacterium damselae subsp. piscicida. Syst Appl Microbiol 20, 634-639.

Mesbah, M., Premachandran, U. \& Whitman, W. B. (1989). Precise measurement of the $\mathrm{G}+\mathrm{C}$ content of deoxyribonucleic acid by high-performance liquid chromatography. Int $J$ Syst Bacteriol 39, 159-167.

Oraic, D., Zrncic, S. \& Sostaric, B. (1998). The most prevalent diseases in cultivated sea bass (Dicentrarchus labrax) and sea bream (Sparus aurata) in fish farms along the Croatian coast. In Abstracts of the 3 rd International Symposium on Aquatic Animal Health, p. 25. Baltimore, MD: APC Press.

Pitcher, D. G., Saunders, N. A. \& Owen, R. J. (1989). Rapid extraction of bacterial genomic DNA with guanidium thiocyanate. Lett Appl Microbiol 8, 151-156.

Romaldo, J. L., Magariños, B., Turnbull, K. D., Baya, A. N., Barja, J. M. \& Toranzo, A. E. (1995). Fatty acid profiles of 'Pasteurella' piscicida: comparison with other fish pathogenic gram-negative bacteria. Arch Microbiol 163, 211-216.

Sneath, P. H. A. \& Sokal, R. R. (1973). Numerical Taxonomy: the 
Principles and Practice of Numerical Classification, 2nd edn. San Francisco, CA: W. H. Freeman.

Snieszko, S. F., Bullock, G. L., Hollis, E. \& Boone, J. G. (1964). Pasteurella sp. from an epizootic of white perch (Roccus americanus) in Chesapeake Bay tidewater areas. J Bacteriol $\mathbf{8 8}$, 1814-1815.

Thyssen, A., Grisez, L., Van Houdt, R. \& Ollevier, F. (1998). Phenotypic characterization of the marine pathogen Photobacterium damselae subsp. piscicida. Int J Syst Bacteriol 48, 1145-1151.

Toranzo, A. E., Barja, J. L., Colwell, R. R. \& Hetrick, F. M. (1983).
Characterization of plasmids in bacterial fish pathogens. Infect Immun 69, 184-192.

Toranzo, A. E., Barreiro, S., Casal, J. F., Figueras, A., Magariños, B. \& Barja, J. (1991). Pasteurellosis in cultured gilthead sea bream (Sparus aurata): first report in Spain. Aquaculture 99, 1-15.

Vauterin, L. \& Vauterin, P. (1992). Computer-aided objective comparison of electrophoresis patterns for grouping and identification of microorganisms. Eur Microbiol 1, 37-41.

Vos, P., Hogers, R., Bleeker, M. \& 8 other authors (1995). AFLP: a new technique for DNA fingerprinting. Nucleic Acids Res 23, 4407-4414. 